\title{
Morphological diversity of cassava accessions of the south-central mesoregion of the State of Mato Grosso, Brazil
}

\author{
B.W. Zago ${ }^{1}$, M.A.A. Barelli ${ }^{2}$, E.S.S. Hoogerheide ${ }^{3}$, C.L. Corrêa ${ }^{4}$, \\ G.I.S. Delforno ${ }^{5}$ and C.J. da Silva ${ }^{6}$ \\ ${ }^{1}$ Programa de Pós-Graduação em Biodiversidade e Biotecnologia da Amazônia \\ Legal, Rede Bionorte, Universidade do Estado de Mato Grosso, \\ Cáceres, MT, Brasil \\ ${ }^{2}$ Departamento de Agronomia, Universidade do Estado de Mato Grosso, Cáceres, \\ MT, Brasil \\ ${ }^{3}$ Empresa Brasileira de Pesquisa Agropecuária - Embrapa Agrossilvipastoril, \\ Sinop, MT, Brasil \\ ${ }^{4}$ Programa Nacional de Pós-Doutorado em Genética e Melhoramento de Plantas, \\ Universidade do Estado de Mato Grosso, Cáceres, MT, Brasil \\ ${ }^{5}$ Faculdade de Ciências Biológicas e Agrárias, \\ Universidade do Estado de Mato Grosso, Cáceres, MT, Brasil \\ ${ }^{6}$ Rede Bionorte, Doutorado em Biodiversidade e Biotecnologia da Amazônia Legal, \\ Cáceres, MT, Brasil
}

Corresponding author: B.W. Zago

E-mail: brunowzago@hotmail.com

Genet. Mol. Res. 16 (3): gmr16039725

Received May 15, 2017

Accepted July 10, 2017

Published August 17, 2017

DOI http://dx.doi.org/10.4238/gmr16039725

Copyright $(C 2017$ The Authors. This is an open-access article distributed under the terms of the Creative Commons Attribution ShareAlike (CC BY-SA) 4.0 License.

ABSTRACT. Genetic variability of cassava (Manihot esculenta Crantz) in Brazil is wide, being this the result of natural and cultural selection during pre- and post-domestication of the species in different environments. Given the number of species of the genus found in the region (38 of a total of 98 species), the central region of Brazil was defined as the primary center of cassava diversity. Therefore, genetic diversity characterization 
of cassava accessions is fundamental, both for farmers and for plant breeders, because it allows the organization of genetic resources and better utilization of available genetic diversity. This research aims to assess genetic divergence of cassava accessions from the south-central region of the State of Mato Grosso, based on multi-categorical morphological traits. For this purpose, 38 qualitative and quantitative morphological descriptors were used. Genetic diversity was expressed by the genetic similarity index, with subsequent clustering of accessions by the modified Tocher's procedure and UPGMA. Of 38 descriptors, only growth habit of stem showed no variability. Tocher and UPGMA methods were efficient and corroborated on group composition. Both methods were able to group accessions of different localities in distinct group consistency.

Key words: Manihot esculenta Crantz; Multivariate analysis; Genetic variability

\section{INTRODUCTION}

Cassava (Manihot esculenta Crantz) is cultivated in almost all States of the Brazilian Federation, with a consequent diversity of varieties adapted to each different biome, providing a wide genetic diversity of the species (Galera and Valle, 2007). Brazil is considered as probable center of origin and diversification of the species (Gulick et al., 1983; Allem, 1997), and the central region of the country as the primary center of diversity of cassava, due to a significant number of species of the genus (38 of a total of 98 species) identified in this region (Lorenzi and Dias, 1993; Nassar, 2000; Olsen, 2004).

Genetic variability of cassava in Brazil is wide, and genetic diversity for almost all characters was identified, including morphological and agronomic traits and resistance to most pests and diseases affecting the crop in the country (Fukuda et al., 1996). A large part of cassava diversity is maintained in germplasm banks, normally consisting of landraces, modern varieties, and wild varieties of the same genus of the crop (Vieira et al., 2008).

To use available genetic variability, genetic material must be properly assembled and evaluated, to enhance chances of selecting genotypes with greater performances on traits of interest (Savita, 2006). Genetic variability can be assessed either by agronomic and morphological traits as well as at molecular level. The main purpose of this evaluation is to remove duplicate accessions and obtain a genetically distinct core sample to be used effectively in breeding programs, thus providing a greater heterotic effect in the progeny (Sudré et al., 2005; Adjebeng-Danquah et al., 2016).

In general, genetic variability studies are performed using multivariate procedures based on dissimilarity measures calculated from a set of traits. By being a unifying analysis, these procedures allow integrating much information extracted from the object of study, proving to be very suitable when there is a high number of accessions (Vidigal et al., 1997; Silva, 2013). This analysis can be complemented by grouping methods as Tocher's optimization and unweighted pair group method using the arithmetic average (UPGMA), whose function is to group the accessions based on its similarities.

Because agility and ease, the assessment of genetic variability based on morphological characterization through multivariate procedures has been carried out in many cultures, like

Genetics and Molecular Research 16 (3): gmr16039725 
soybean (Val et al., 2014), macaw palm (Domiciano et al., 2015), pepper (Costa et al., 2015), wheat (Bertan et al., 2006), and cassava (Albuquerque et al., 2009; Campos et al., 2010; Adjebeng-Danquah et al., 2016). Besides, this tool proved to be useful for guiding germplasm conservation and maintaining biodiversity, as well as guiding crop improvement efforts for the development of more productive varieties adapted to each region (Mtunguja et al., 2015). In this study, we aimed to evaluate the genetic divergence of cassava accessions from south central mesoregion of the State of Mato Grosso, Brazil, based on morphological traits.

\section{MATERIAL AND METHODS}

\section{Germplasm}

We evaluated 158 accessions of cassava from the Mato Grosso's State University (UNEMAT - Cáceres) and Brazilian Agricultural Research Corporation (EMBRAPA Agrossilvipastoril) collections. These accessions are from five different municipalities: Rosário Oeste (UNRO), Cáceres (UNCA), Cuiabá (UNCA), Poconé (EMPO), and Jangada (EMJA), which are located in the south-central mesoregion of the State of Mato Grosso.

\section{Planting}

Cassava accessions were planted in the agricultural year 2014/2015, at the experimental area of the Laboratory of Genetic Resources and Biotechnology, UNEMAT - Cáceres. We replicated 10 clones of each accession in rows spaced $1 \mathrm{~m}$ to avoid competition between clones. Cultural treatments were carried out as recommended for the crop (Souza and Fialho, 2003).

\section{Morphological characterization}

Morphological characterization was performed using 38 quantitative and qualitative descriptors of proposed by Fukuda and Guevara (1998) (Table 1). Quantitative morphological descriptors with no pre-defined phenotypic categories were classified using the Genes software function "Recoding quantitative/Multi-category".

As recommended by the authors, characterization of leaf and petiole was performed 6 to 8 months after planting, and stem and root were performed at harvesting time, established as 12 months after planting.

\section{Data analysis}

Multi-categorical matrix was obtained to estimate genetic distance between each pair of accessions using the similarity genetic index based on multi-categorical variables. This index generates a genetic similarity (GS) matrix taking into account the occurrence of agreement (a) and disagreement $(\mathrm{d})$ between the values $\left(\mathrm{S}_{\mathrm{ii}}=\mathrm{a} / \mathrm{d}+\mathrm{a}\right)$. The genetic similarity matrix was transformed into a genetic dissimilarity matrix (GD) through the estimated similarity matrix complement (GD = 1 - GS).

Based on the genetic dissimilarity matrix, accessions were arranged into groups using the modified Tocher's optimizations procedure, and dendrograms were built through the unweighted pair group method using the arithmetic average (UPGMA) (Rolf, 1993). All data were analyzed with the Genes statistical free software (Cruz, 2008).

Genetics and Molecular Research 16 (3): gmr16039725 
Table 1. Morphological traits used to evaluate 158 accessions of cassava (Manihot esculenta Crantz) ${ }^{1}$.

\begin{tabular}{|c|c|}
\hline Trait $^{2}$ & Phenotypic categories \\
\hline 1. Color of apical leaves & 3 - light green; 5 - dark green; 7 - purplish-green; 9 - purple. \\
\hline 2. Pubescence on apical leaves & 0 - absent; 1 - present. \\
\hline 3. Shape of central leaflet & $\begin{array}{l}1 \text { - ovoid; } 2 \text { - elliptical-lanceolate; } 3 \text { - obovate-lanceolate; } 4 \text { - oblong-lanceolate; } 5 \text { - lanceolate; } 6 \text { - straight } \\
\text { or linear; } 7 \text { - pandurate; } 8 \text { - linear-pyramidal; } 9 \text { - linear-pandurate; } 10 \text { - linear-hostatilobalate. }\end{array}$ \\
\hline 4. Color of petiole & 1 - yellowish-green; 2 - green; 3 - reddish-green; 5 - greenish-red; 7 - red; 9 - purple. \\
\hline 5. Color of stem cortex & 1 - yellow; 2 - light green; 3 - dark green. \\
\hline 6. Color of stem exterior & 3 - orange; 4 - greeny-yellowish; 5 - golden; 6 - light brown; 7 - silver; 8 - gray; 9 - dark brown. \\
\hline 7. Extent of root peduncle & 0 - sessile; 3 - pedunculate; 5 - mixed. \\
\hline 8. External color of storage root & 1 - white or cream; 2 - yellow; 3 - light brown; 4 - dark brown. \\
\hline 9. Color of root cortex & 1 - white or cream; 2 - yellow; 3 - pink; 4 - purple. \\
\hline 10. Color of root pulp (parenchyma) & 1 - white; 2 - cream; 3 - yellow; 4 - pink. \\
\hline 11. Texture of root epidermis & 3 - smooth; 7 - rough. \\
\hline 12. Flowering & 0 - absent; 1 - present. \\
\hline 13. Leaf color & 3 - light green; 5 - dark green; 7 - purple green; 9 - purple. \\
\hline 14. Color of stem epidermis & 1 - cream; 2 - light brown; 3 - dark brown; 4 - orange. \\
\hline 15. Growth habit of stem & 1 - straight; 2 - zig-zag. \\
\hline 16. Color of end branches in adult plants & 3 - green; 5 - green-purple; 7 - purple. \\
\hline 17. Root constriction & 1 - few to no; 2 - some; 3 - many. \\
\hline 18. Color of leaf vein & $\begin{array}{l}3 \text { - green; } 5 \text { - reddish-green in less than half of the lobe; } 7 \text { - reddish-green in more than half of the lobe; } 9 \text { - } \\
\text { all red. }\end{array}$ \\
\hline 19. Orientation of petiole & 1 - inclined upwards; 3 - horizontal; 5 - inclined downwards; 7 - irregular. \\
\hline 20. Length of stipules & 3 - short; 5 - long. \\
\hline 21. Stipule margin & 1 - split or forked; 2 - entire. \\
\hline 22. Branching habit & 1 - erect; 2 - dichotomous; 3 - trichotomous; 4 - tetrachotomous. \\
\hline 23. Lobe margins & 3 - smooth; 7 - winding. \\
\hline 24. Root shape & 1 - conical; 2 - conical-cylindrical; 3 -cylindrical; 4 - irregular. \\
\hline 25. Shape of plant & 1 - compact; 2 - open; 3 - umbrella; 4 - cylindrical. \\
\hline 26. Root epidermis: ease of peeling & 3 - easy; 4 - difficult. \\
\hline 27. Root cortex: ease of peeling & 3 - easy; 7 - difficult. \\
\hline 28. Root position & 1 - vertical trend; 2 - horizontal trend; 3 -irregular. \\
\hline 29. Postharvest deterioration & $\begin{array}{l}1 \text { - no deterioration; } 2 \text { - up to } 20 \% \text { of roots deteriorated; } 3-20-40 \% \text { of roots deteriorated; } 4-41-60 \% \text { of } \\
\text { roots deteriorated; } 5 \text { - more than } 60 \% \text { of roots deteriorated. }\end{array}$ \\
\hline 30. Distance between leaf scars & 3 - short $(\leq 8 \mathrm{~cm}) ; 5$ - medium $(8-15 \mathrm{~cm}) ; 7$ - long $(\geq 15 \mathrm{~cm})$. \\
\hline 31. Number of leaf lobes & 1 - three lobes; 3 - five lobes; 5 - seven lobes; 7 - nine lobes; 9 - eleven lobes. \\
\hline 32. Average root length & 1 - short $(\leq 20 \mathrm{~cm}) ; 2$ - intermediate (between 20 and $30 \mathrm{~cm})$; long $(\geq 30 \mathrm{~cm})$. \\
\hline 33. Average root diameter & 1 - thin $(\leq 5 \mathrm{~cm}) ; 2$ - intermediate (between 5 and $8 \mathrm{~cm})$; thick $(\geq 8 \mathrm{~cm})$. \\
\hline 34. Length of leaf lobe & Measured from the intersection of all lobes to the end of the middle lobe. Expressed in $\mathrm{cm}$. \\
\hline 35. Width of leaf lobe & Measured from the widest part of the middle lobe. Expressed in $\mathrm{cm}$. \\
\hline 36. Ratio length/width of central leaf lobe & Quotient of the division of the length of central leaf lobe by the width of central leaf lobe. \\
\hline 37. Petiole length & Observed from the middle third of the plant. Expressed in $\mathrm{cm}$; \\
\hline 38. Angle of branching & Measured at first primary branching. \\
\hline
\end{tabular}

${ }^{1}$ Accessions from Embrapa Agrossilvipastoril and Unemat - Cáceres cassava collections. ${ }^{2}$ Morphological traits proposed by Fukuda and Guevara (1998).

\section{RESULTS AND DISCUSSION}

Of the 38 traits evaluated, 37 showed variability for the 158 cassava accessions. Only for the trait growth habit of the stem, it was not detected any variation; the stem of all accessions was considered "straight". Thus, by not presenting variability, the trait was not considered to obtain the dissimilarity matrix. Similar results regarding this trait were also found by Vieira et al. (2007), who evaluated 357 accessions belonging to the Embrapa-Cerrado collection and by Egewarth (2014) who studied 24 genotypes in the western region of Pará. As reported by Vieira et al. (2007), this fact may indicate that during domestication of the crop, a preference to genotypes with a straight stem was given.

Among the evaluated traits, some related to root are of great importance for the genetic improvement of the crop. According to Vieira et al. (2008), there are some patterns of preference and following this information, the accessions that we evaluated were distributed as follows: Color of root pulp: farmers and consumers prefer genotypes with yellow color of pulp; among the accessions that we evaluated, $7.60 \%$ had yellow pulp, $20.25 \%$ white color,

Genetics and Molecular Research 16 (3): gmr16039725 
$70.60 \%$ cream pulp, and $1.55 \%$ pink pulp. Color of root cortex: the industry prefers genotypes with white color of the cortex, $41.78 \%$ of the accessions fit this pattern, $31.01 \%$ had a pink cortex, $16.45 \%$ yellow cortex, and $10.76 \%$ purple cortex. External color of storage root: the industry preference is for genotypes with white or external cream color; however, when it comes to the consumption "in natura", consumers prefer genotypes with a light brown or dark brown external color; among the accessions we evaluated, $14.56 \%$ presented white or external cream color, while $51.90 \%$ presented brown color, $32.28 \%$ dark brown, and $1.26 \%$ yellow. Root constriction: breeding programs have a preference for varieties with few or no constriction, $58.23 \%$ of the accessions that we evaluated showed this pattern, while $41.77 \%$ had some constrictions.

Other characteristics mentioned by Vieira et al. (2008) as ease peel of root cortex and epidermis are also of great interest, since genotypes with easy peel are preferred by consumers and industry; among the accessions that we evaluated, $66.24 \%$ had easy peeling cortex, while for the epidermis $52.87 \%$ were easy to peel. For the variable extent of root peduncle, the genotypes with short or sessile peduncles are ideal, $54.19 \%$ of the accessions had this characteristic, while $43.87 \%$ had long peduncles.

Root length and width are also economically important, since plants with roots too long and too thick may indicate plants with more than one vegetation cycle, which may cause a significant loss of culinary quality of roots, being undesirable for consumption "in natura", but desirable for industrial use. Therefore plant breeders prefer genotypes with medium size roots (Vieira et al., 2008); $50.63 \%$ of the accessions showed this characteristic, $36.70 \%$ were classified as long, and $12.67 \%$ were classified as short. Concerning diameter, $55.06 \%$ were considered medium or intermediate, $44.31 \%$ were considered thin, and $0.63 \%$ was considered thick.

\section{Multivariate analysis}

Dissimilarity matrix based on 37 multi-categorical morphological traits showed a wide genetic variability since the estimation of dissimilarity $\left(\mathrm{d}_{\mathrm{ii}}\right)$ was considered high, ranging from 0.13 to 0.84 . Accession combinations with the lowest dissimilarity were UNCA-31 and UNRO-17 ( $\left.\mathrm{d}_{\mathrm{ii}}, 0.13\right)$, with 32 similar traits. Both accessions had a red petiole, a gray external color of the stem, dark brown external color of storage root, cream color of root pulp, average length, and thin diameter of roots.

The combination with the highest dissimilarity was between accessions UNCA-41 and UNCA-39 (dii' 0.84), which diverged in 31 traits. While UNCA-41 had a purple petiole, dark brown external color of stem and root, yellow color of root pulp, long length, and average diameter of the root, UNCA-39 had yellowish-green petiole, light brown external color of stem and root, cream color of root pulp, average length, and thin diameter of roots. This accession had high average divergence concerning all accessions evaluated, which according to Kvitschal et al. (2009) indicate that the accession mentioned above tend to provide a satisfactory heterotic effect when used as parental in a breeding program.

These results led us to establish that the accessions of cassava evaluated in this study have wide genetic basis; such variability can be explained by the fact that smallholder farmers maintain a high genetic variability under cultivation, since they usually grow large number of genotypes together and constantly introduce new genotypes to their crops (Bellon, 1996; Sambatti et al., 2000). Besides, smallholder farmers often do not discard low yield landraces, keeping them in lower density, expecting that they become productive under different climatic conditions (Peroni et al., 1999; Fregene et al., 2003).

Genetics and Molecular Research 16 (3): gmr16039725 
The modified Tocher's optimization procedure indicated 22 different groups of cassava accessions. Highest average intra-group dissimilarity was observed in groups VII, XVII, XXI, and XXII $\left(d_{I V} ; d_{V}=0.540\right)$ and lowest average intra-group dissimilarity in groups I, II, and VI $\left(d_{I V} ; d_{V}=0.378\right)$ (Table 2).

Table 2. Grouping generated by the modified Tocher's optimization procedure based on analysis of dissimilarity estimated using 37 multi-categorical morphological traits of 158 cassava accessions from the south-central mesoregion of the State of Mato Grosso.

\begin{tabular}{l|c|l|c}
\hline Group & Number of accessions & Accessions & $\begin{array}{c}\text { Average intra-group } \\
\text { dissimilarity }\end{array}$ \\
\hline I & 18 & $\begin{array}{l}\text { UNCA-31, UNRO-17, UNRO-13, UNCA-37, UNCA-27, UNCA-10, UNRO-18, UNRO-04, UNCA-20, } \\
\text { UNCA-06, UNCA-34, UNCA-12, UNCA-25, UNRO-14, EMJA-18, UNCA-29, UNCA-19, UNRO-19 }\end{array}$ & 0.378 \\
\hline II & 17 & $\begin{array}{l}\text { EMPO-08, EMJA-15, EMCB-23, EMCB-22, EMCB-24, EMCB-26, EMPO-11, EMPO-05, EMCB-18, } \\
\text { EMCB-29, EMJA-16, EMJA-33, EMJA-37, EMJA-24, EMJA-09, EMJA-28, UNCA-44 }\end{array}$ & 0.378 \\
\hline III & 16 & $\begin{array}{l}\text { EMCB-34, EMCB-33, EMCB-02, EMCB-21, EMCB-11, EMCB-05, EMPO-09, EMJA-23, EMCB-06, } \\
\text { EMCB-07, EMCB-20, EMPO-06, EMPO-10, EMCB-10, EMJA-42, EMCB-16 }\end{array}$ & 0.405 \\
\hline IV & 16 & $\begin{array}{l}\text { EMJA-03, EMJA-10, EMJA-17, EMJA-27, EMJA-39, EMJA-40, EMCB-27, EMCB-31, EMJA-30, } \\
\text { EMJA-31, EMJA-21, EMJA-25, EMJA-20, EMPO-12, EMJA-05, EMJA-06 }\end{array}$ & 0.405 \\
\hline V & 13 & UNRO-08, UNCA-17, UNCA-26, UNCA-21, UNRO-07, UNCA-05, UNCA-01, UNCA-28, UNRO-10, & 0.405 \\
\hline VI & 11 & UNRO-02, UNCA-04, EMJA-41, EMCB-17 & 0.378 \\
\hline VII & 8 & UNCA-24, UNCA-42, UNCA-15, UNCA-22, UNRO-16, UNCA-30, UNCA-33, UNCA-07, UNCA-02, & \\
\hline VIII & 7 & EMJA-08, EMJA-38, EMJA-36, EMJA-32, EMJA-12, EMJA-26, EMJA-29, EMCB-03 & 0.03 \\
\hline IX & 7 & UNCA-09, UNRO-09, UNRO-03, UNRO-05, UNRO-11, UNCA-18, UNRO-12 & 0.540 \\
\hline X & 7 & UNRO-22, EMJA-14, UNCA-16, UNCA-35, UNCA-32, UNCA-36, UNCA-38 & 0.405 \\
\hline XI & 7 & EMCB-19, EMJA-07, EMJA-35, EMJA-01, EMJA-19, EMCB-35, EMPO-07 & 0.405 \\
\hline XII & 4 & UNCA-43, EMCB-09, EMCB-08, EMCB-28 & 0.416 \\
\hline XIII & 4 & EMCB-01, EMCB-32, EMCB-15, EMPO-01 & 0.416 \\
\hline XIV & 4 & EMCB-14, EMJA-04, EMCB-25, EMJA-22 & 0.416 \\
\hline XV & 3 & UNCA-39, EMJA-02, EMCB-37 & 0.459 \\
\hline XVI & 3 & UNCA-08, UNRO-15, UNCA-23 & 0.513 \\
\hline XVII & 3 & EMCB-04, EMPO-04, EMCB-13 & 0.416 \\
\hline XVIII & 2 & UNCA-40, EMCB-30 & 0.432 \\
\hline XIX & 2 & UNRO-20, EMCB-36 & 0.540 \\
\hline XX & 2 & UNCA-11, EMPO-03 & 0.432 \\
\hline XXI & 2 & UNRO-06, EMJA-43 & 0.432 \\
\hline XXII & 2 & UNRO-01, UNCA-41 & 0.432 \\
\hline & & & 0.540 \\
\hline
\end{tabular}

Groups I, V, VI, and IX were composed mainly of accessions from Cáceres, encompassing approximately $80 \%$ of all accessions from the municipality. Groups III and XII were composed mainly of accessions from Cuiabá, covering approximately $40 \%$ of all accessions from the municipality. Groups IV and VII were composed mainly of accessions from Jangada, encompassing approximately $50 \%$ of all accessions from the municipality. Accessions from Rosário Oeste and Poconé were not clustered in an individual group or concentrated in a few groups, although Rosário Oeste accessions tended to group with Cáceres accessions, as well as Poconé accessions, which tended to group with accessions from Jangada and Cuiabá.

The fact that some groups were formed based on the accessions of origin reinforces the idea of exchange varieties within communities of the same municipality, as discussed by Amorozo (2000). According to Oler (2012), there is a demand by farmers in diversifying their collection to improve the adaptation to changes, such as environmental or socioeconomic changes. Consequently, the process of exchanging "manivas" (stem cuttings) between communities can result in homogeneity of accessions within a region and heterogeneity among different regions, due to the selection of varieties in the face of local environmental characteristics.

The accessions within each group presented average intra-group genetic similarity greater than 0.56 , which allows admitting that the groups are homogeneous. A similar 
result was reported by Vieira et al. (2007), where average intra-group genetic similarity, obtained by analyzing the genetic variability of Embrapa-Cerrado's cassava collection through morphological descriptors, was greater than 0.59. According to the same author, the establishment of groups with homogeneity within the groups and heterogeneity between groups can be the starting point for a more detailed evaluation of the accessions, aiming at its use directly by a researcher in breeding programs.

UPGMA method (Figure 1) allowed the formation of six groups of different sizes, considering a cutting line at $80 \%$, established by the $t$-test for significance. Accessions UNRO01 and UNCA-41 (Group 1) were the most divergent because they were those that presented the greatest distances concerning the majority of accessions. Cophenetic correlation coefficient magnitude was low (0.56), showing poor fit between the graphical representation and the original dissimilarity matrix (Rolf, 1993). Although according to Vaz Patto et al. (2004), cophenetic correlation coefficients $\geq 0.56$ indicate that the dendrogram reproduces satisfactorily the information contained in the correlation matrix, and in the consequent cluster formation.

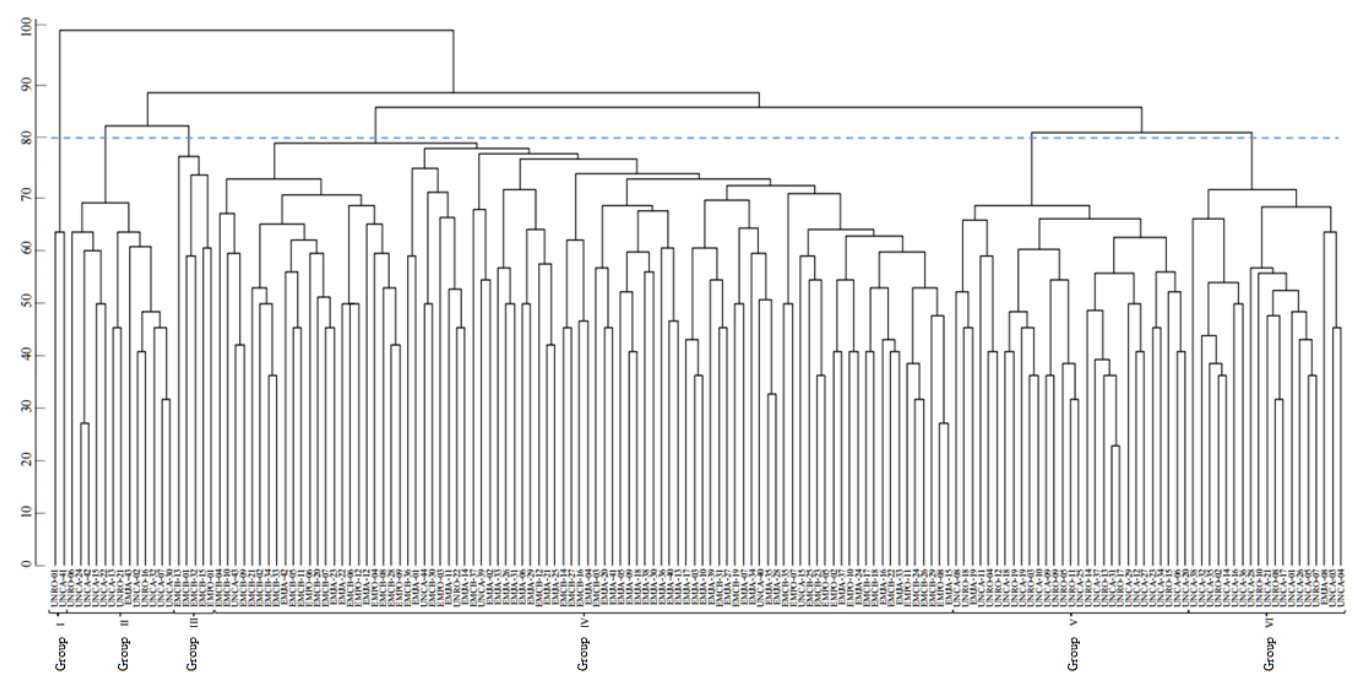

Figure 1. Dendrogram representing the grouping of 158 accessions of cassava, coming from the south-central region of the State of Mato Grosso, by the method of UPGMA, based on the dissimilarity estimated from morphological characteristics.

A low cophenetic correlation coefficient does not mean that the dendrogram has no utility, but only indicates that some distortion might have occurred (Mohammadi and Prasanna, 2003). With distance matrices as the input of clustering, the magnitude of cophenetic correlation coefficient decreases if the number of individual increases to about 50 (Rolf and Fisher, 1968).

Although the UPGMA method has formed fewer groups than the Tocher procedure, the grouping of accessions made by UPGMA was similar to Tocher procedure, as can be observed in UPGMA Group I, which grouped the same accessions of Tocher Group XXII. UPGMA Group II encompassed all accessions of Tocher Groups VI and XI. UPGMA Group III was similar to Tocher Group XIII, except for accession EMCB-13, which in Tocher procedure had

Genetics and Molecular Research 16 (3): gmr16039725 
been grouped with other accessions. UPGMA Group IV are the largest group (90), most of them from the municipality of Jangada (40) and Cuiabá (33), and in Tocher procedure, these accessions were in numerous groups. However, it is possible to observe that the methods corroborated when separating accessions according to their locality. Groups V and VI were constituted of 29 and 19 accessions, respectively. When compared to Tocher procedure, it is possible to notice that UPGMA Group V grouped all accessions from Cáceres and Rosário Oeste of Tocher Groups I, VIII, XVI, and XX, while UPGMA Group VI encompassed all accessions of Tocher Groups VI and IX.

Similar results were found by Egewarth (2014), who observed comparable behavior among Tocher and UPGMA methods when evaluating 24 cassava genotypes collected in the western region of Pará-Brazil. Similarity, the discrimination of genotypes between these methods was also reported in studies with other crops as observed by Amaral Jr et al. (1999) in pumpkin, Simon et al. (2012) in maize, Barelli et al. (2006) and Teixeira et al. (2013) in common bean, and in chili by Leite (2014). Kvitschal et al. (2009) also noted similarities between Tocher and UPGMA methods and concluded that, although both have not been identical, one method completes the other.

Both collections revealed a wide range of genetic diversity and showed the existence of high morphological variability among cassava accessions. Morphological traits offer a quick and efficient evaluation tool to assess germplasm diversity and were capable of separating accessions according to sampling locations in both clustering methods even though they were sampled in the same mesoregion of the State of Mato Grosso.

Furthermore, morphological characterization and the establishment of genetic distance between the accessions are significant subsidies to choose different progenitors for the development of segregating populations, enabling using accessions with desirable traits in future cassava breeding programs.

\section{CONCLUSIONS}

Cassava accessions assessed in this study presented genetic variability for the morphological traits evaluated.

Of the 38 characteristics evaluated, 37 had variability for the 158 accessions, demonstrating the efficiency of morphological descriptors for the assession of cassava genetic variability.

Tocher and UPGMA methods were efficient and agreed on group composition. Both methods could group accessions of different localities in distinct group consistency.

\section{ACKNOWLEDGMENTS}

The authors are thankful to CNPq and FAPEMAT for scholarships and research funding.

\section{REFERENCES}

Adjebeng-Danquah J, Gracen VE, Offei SK, Asante IK, et al. (2016). Agronomic performance and genotypic diversity for morphological traits among cassava genotypes in the Guinea Savannah Ecology of Ghana. J. Crop Sci. Biotechnol. 19: 99-108. https://doi.org/10.1007/s12892-015-0095-8

Albuquerque JAA, Sediyama T, Silva AA, Sediyama CS, et al. (2009). Caracterização morfológica e agronômica de clones de mandioca cultivados no Estado de Roraima. Braz. J. Agric. Sci. 4: 388-394.

Genetics and Molecular Research 16 (3): gmr16039725 
Allem AC (1997). A reappraisal on the geographical origin of cassava (Manihot esculenta, Euphorbiaceae). In: Anais do $1^{\circ}$ Simpósio Latino-Americano de Recursos Genéticos Vegetais, Campinas.

Amaral Jr AT, Casali V, Cruz C and Finger F (1999). Divergência genética entre acessos de moranga do banco de germoplasma de hortaliças da Universidade Federal de Viçosa. Hortic. Bras. 17: 3-6.

Amorozo MCM (2000). Management and conservation of Manihot esculenta Crantz. germplasm by traditional farmers in Santo Antônio do Leverger, Mato Grosso State, Brazil. Etnoecologica 4: 69-83.

Barelli MAA, Gonçalves-Vidigal MC, Thomazella C, Vidigal Filho PS, et al. (2006). Genetic diversity among common bean (Phaseolus vulgaris L.) accessions based on RAPD markers. Annu. Rep. Bean Improv. Coop. 49: 131-132.

Bellon MR (1996). The dynamics of crop intraspecific diversity: a conceptual framework at the farmer level. Econ. Bot. 50: 26-39. https://doi.org/10.1007/BF02862110

Bertan I, Carvalho FIF, Oliveira AC, Vieira EA, et al. (2006). Comparação de métodos de agrupamento na representação da distância morfológica entre genótipos de trigo. R. Bras. Agrociênc 12: 279-286.

Campos AL, Zacarias AJ, Costa DL, Neves LG, et al. (2010). Avaliação de acessos de mandioca do banco de germoplasma da UNEMAT Cáceres-Mato Grosso. R. Tróp. Cienc. Agr. Biol 4: 44-54.

Costa LV, Bentes JLS, Lopes MTG, Alves SRM, et al. (2015). Caracterização de acessos de pimentas do Amazonas. Hortic. Bras. 33: 290-298. https://doi.org/10.1590/S0102-053620150000300003

Cruz CD (2008). Programa GENES: Diversidade genética. 1st edn. Universidade Federal de Viçosa Press, Viçosa.

Domiciano GP, Alves AA, Laviola BG and Conceição LDHS (2015). Parâmetros genéticos e diversidade em progênies de Macaúba com base em características morfológicas e fisiológicas. Cienc. Rural 45: 1599-1605. https://doi. org/10.1590/0103-8478cr20140909

Egewarth JF (2014). Diversidade genética entre cultivares de mandioca da Região Oeste do Paraná. Master's thesis, UNIOESTE, Marechal Cândido Rondon.

Fregene MA, Suarez M, Mkumbira J, Kulembeka H, et al. (2003). Simple sequence repeat marker diversity in cassava landraces: genetic diversity and differentiation in an asexually propagated crop. Theor. Appl. Genet. 107: 1083-1093. https://doi.org/10.1007/s00122-003-1348-3

Fukuda WMG, Silva SO and Mendes RA(1996). Caracterização morfológica e agronômica do banco ativo de germoplasma de mandioca do Centro Nacional de Pesquisa de Mandioca e Fruticultura Tropical. In: Anais do $1^{\circ}$ Congresso Latino Americano de Raízes Tropicais e $1^{\circ}$ Congresso Brasileiro de Mandioca, São Paulo.

Fukuda WMG and Guevara CL (1998). Descritores morfológicos e agronômicos para a caracterização de mandioca (Manihot esculenta Crantz). EMBRAPA - Centro Nacional de Pesquisa de Mandioca e Fruticultura Tropical, Cruz das Almas.

Galera JMSV and Valle TL (2007). Estruturação genética do germoplasma de mandioca através de informações comparativas entre estudos biológicos e antropológicos - resultados preliminares. Rev. Raizes Amidos Trop 3: 363-366.

Gulick R, Hershey CH and Alcazar JE (1983). Genetic resources of cassava and wild relatives. International Board for Plant Genetic Resources, Rome.

Kvitschal MV, Vidigal Filho PS, Scapim CA, Gonçalves-Vidigal MC, et al. (2009). Comparison of methods for phenotypic stability analysis of cassava (Manihot esculenta Crantz) genotypes for yield and storage root dry matter content. Braz. Arch. Biol. Technol. 52: 163-175. https://doi.org/10.1590/S1516-89132009000100022

Leite PSS (2014). Variabilidade intraespecífica para caracteres morfológicos, agronômicos e moleculares entre acessos de Capsicum baccatum var. pendulum. Master's thesis, UENF, Campos dos Goytacazes.

Lorenzi JO and Dias CA (1993). Cultura da mandioca. Boletim Técnico. Coordenadoria de Assistência Técnica Integral, Campinas.

Mohammadi SA and Prasanna BM (2003). Analysis of genetic diversity in crop plants - salient statistical tools and considerations. Crop Sci. 43: 1235-1248. https://doi.org/10.2135/cropsci2003.1235

Mtunguja MK, Ranjan A, Laswai HS, Muzanila Y, et al. (2015). Genetic diversity of farmer-preferred cassava landraces in Tanzania based on morphological descriptors and single nucleotide polymorphisms. Plant Genet. Resour. 15: 138146. https://doi.org/10.1017/S1479262115000453

Nassar NMA (2000). Cytogenetics and evolution of Cassava (Manihot esculenta Crantz). Genet. Mol. Biol. 23: 1003-1014. https://doi.org/10.1590/S1415-47572000000400046

Oler JRL (2012). Conservação da agrobiodiversidade por agricultores de pequena escala em Mato Grosso. Master's thesis, UNESP, Rio Claro.

Olsen KM (2004). SNPs, SSRs and inferences on cassava's origin. Plant Mol. Biol. 56: 517-526. https://doi.org/10.1007/ s11103-004-5043-9

Peroni N, Martins PS and Ando A (1999). Diversidade inter e intra-específica e uso de análise multivariada para morfologia da mandioca (Manihot esculenta Crantz): um estudo de caso. Sci. Agric. 56: 1999. https://doi.org/10.1590/S0103$\underline{90161999000300011}$

Genetics and Molecular Research 16 (3): gmr16039725 
Rolf F (1993). NTSYS - PC numerical taxonomy and multivariate analysis system, version 1.70. Exeter Publishing, New York.

Rolf FJ and Fisher DR (1968). Tests for hierarchical structure in random data sets. Syst. Zool. 17: 407-412. https://doi. org $/ 10.2307 / 2412038$

Sambatti JBM, Martins PS and Ando A (2000). Distribuição da diversidade isoenzimática e morfológica da mandioca autóctone de Ubatuba. Sci. Agric. 57: 75-80. https://doi.org/10.1590/S0103-90162000000100013

Savita SG (2006). Diversity of linseed germplasm for yield and yield components. Doctoral thesis, University of Agricultural Sciences, Dharwad.

Silva CJ (2013). Caracterização agronômica e divergência genética de acessos de cártamo. Doctoral thesis, UNESP, Botucatu.

Simon GA, Kamada T and Moiteiro M (2012). Divergência genética em milho de primeira e segunda safra. Semin. Cienc. Agrar. 33: 449-458.

Souza LDS and Fialho JDF (2003). Cultivo da mandioca para a região do cerrado. EMBRAPA - Centro Nacional de Pesquisa de Mandioca e Fruticultura Tropical, Cruz da Almas. Available at [https://sistemasdeproducao.cnptia. embrapa.br/FontesHTML/Mandioca/mandioca_cerrados/index.htm]. Accessed April 7, 2017.

Sudré CP, Rodrigues R, Riva EM, Karasawa M, et al. (2005). Divergência genética entre acessos de pimenta e pimentão utilizando técnicas multivariadas. Hortic. Bras. 23: 22-27. https://doi.org/10.1590/S0102-05362005000100005

Teixeira AL, Gonçalves FMA, Rezende JC, Rocha RB, et al. (2013). Análise de componentes principais em caracteres morfológicos de café arábica em estádio juvenil. Coffee Sci. 8: 205-210.

Val BHP, Ferreira JA, Junior., Bizari EH, Di Mauro AO, et al. (2014). Diversidade genética de genótipos de soja por meio de caracteres agromorfológicos. Ciênc. Tecnol. 6: 72-83.

Vaz Patto MC, Satovic Z, Pêgo S and Fevereiro P (2004). Assessing the genetic diversity of Portuguese maize germplasm using microsatellite markers. Euphytica 137: 63-72. https://doi.org/10.1023/B:EUPH.0000040503.48448.97

Vidigal GMC, Vidigal Filho OS, Amaral AT, Junior. and Braccini AL (1997). Divergência genética entre cultivares de mandioca por meio de estatística multivariada. Bragantia 56: 263-271. https://doi.org/10.1590/S0006$\underline{87051997000200005}$

Vieira EA, Fialho JF, Faleiro FG, Fukuda WMG, et al. (2005). Variabilidade genética para caracteres morfológicos entre acessos do banco de germoplasma de mandioca da Embrapa Cerrados. In: Anais do $11^{\circ}$ Congresso Brasileiro de Mandioca, Campo Grande.

Vieira EA, Fialho JF, Silva MS and Faleiro FG (2007). Variabilidade genética do banco ativo de germoplasma de mandioca do Cerrado acessada por meio de descritores morfológicos. Boletim de Pesquisa e Desenvolvimento. Embrapa Cerrados, Planaltina.

Vieira EA, Fialho JF, Silva MS, Fukuda WMG, et al. (2008). Variabilidade genética do banco de germoplasma de mandioca da Embrapa cerrados acessada por meio de descritores morfológicos. Científica (Jaboticabal) 36: 56-67.

Genetics and Molecular Research 16 (3): gmr16039725 